\title{
Mehrdad Ehsani, Yimin Gao, Stefano Longo and Kambiz M. Ebrahimi: Modern Electric Hybrid Electric and Fuel Cell Vehicles (3rd Edn)
}

\author{
Edward R. Adlard ${ }^{1}$ \\ ๑) Springer-Verlag GmbH Germany, part of Springer Nature 2018
}

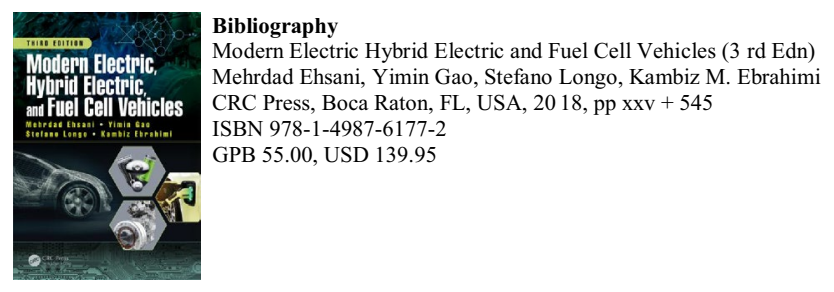

Hybrid vehicles are now commonplace, electric vehicles are less common and fuel cell vehicles are even rarer. Transport contributes about a third of the world's $\mathrm{CO}_{2}$ emissions; the ever-increasing threat of global warming, manifest in drought conditions and forest fires in some parts of the world and floods in others, gives importance to anything that can reduce this $\mathrm{CO}_{2}$ burden, so clearly this book is very relevant.

After an introductory chapter which gives an excellent overview, a further 19 chapters follow ranging from what could be considered to be pure engineering topics such as Chap. 2 on vehicle propulsion to Chap. 15 on fuel cells which is pure physical chemistry. Scientists are divided into two groups - those who envisage problems from a pictorial point of view and those who approach them mathematically. Faraday, who never employed anything beyond simple arithmetic, is an example of the first group, and his near contemporary Gauss an example of the second. The authors of this volume clearly belong to the second group and although everyone can gain something from the book, those with a good mathematical knowledge will gain the most. Each chapter starts with a summary of its contents and it would have been useful if they had ended with a summary of conclusions. The chapters end not with references, but with a bibliography which serves the same purpose. Toyota gets a special mention for its Prius car which represented almost the earliest hybrid vehicle commercially available. Hybrid vehicles are now capable of a performance approaching 100 miles per gallon. There is no mention of solar-powered vehicles which is a pity because solar cell technology is advancing rapidly and vehicles powered by solar cells are as likely as fuel cell vehicles. By coincidence, a recent issue of the journal of the UK Royal Society of Chemistry contains an article on the use of hydrogen as a fuel and from this it would appear that a major obstacle to hydrogen-powered cars is the cost of constructing a distribution network as extensive as that which currently exists for petrol and diesel fuel.

At 545 pages, this book is quite a substantial tome and is not cheap, but for those working in this field it is an essential purchase.
Edward R. Adlard

e.adlard77@btinternet.com

1 Springer, Burton, UK 